\title{
Effect of extrusion-cooking temperature on the nutritive value of lupin seeds in fattening lambs
}

\author{
J. J. Pająk, J. Kowalczyk, T. Żebrowska, B. Kowalik \\ and $\mathrm{Z}$. Dlugołęcka
}

The Kielanowski Institute of Animal Physiology and Nutrition,

Polish Academy of Sciences

05-110 Jablonna, Poland

\begin{abstract}
Twelve Polisin-Merino lambs, divided into two groups of 6 , were fattened from 18 to $39 \mathrm{~kg}$ body weight on diets containing $14 \%$ crude protein and $11 \%$ crude fibre in dry matter; $25 \%$ of crude protein was from untreated lupin seeds or a mixture of lupin extruded at $160^{\circ} \mathrm{C}$ with barley $(1: 1)$. Daily body weight gains of lambs fed extruded lupin seeds were higher $(P<0.5)$ than those of lambs fed the untreated lupine-barley mixture ( 234 vs $186 \mathrm{~g}$ ). Fecd efticiency was $5.0 \mathrm{~kg}$ dry matter and $729 \mathrm{~g}$ crude protein in lambs fed the untreated lupine-barley mixture and $4.2 \mathrm{~kg}$ dry matter and $597 \mathrm{~g}$ crude protein in animals receiving the extruded mixture.

Effective protein degradability of untreated lupin was 0.85 , untreated barley 0.75 or untreated lupin-barley mixture 0.80 , whereas that of extruded at $130,140,150$ or $160^{\circ} \mathrm{C}$ lupin-barley mixtures gradually decreased from 0.70 to 0.67 . The respective effective protein degradability values for barley extruded at 135 or $155^{\circ} \mathrm{C}$ were 0.72 and 0.60 . The coefficient of intestinal protein digestion of untreated lupine was 0.59 , of barley, 0.83 , and of the lupin-barley mixture, 0.71 , whereas for extruded lupin-barley mixtures, it only slightly increased with temperature from 0.92 to 0.94 , while for extruded barley from 0.91 to 0.92 .

Substitution of unprocessed lupin seeds with extruded secds decreased protein degradation in the rumen, increased protein intestinal digestibility and effectiveness of fattening lambs. Increasing the extrusion temperature to over $130^{\circ} \mathrm{C}$ did not significantly improve degradability in the rumen or intestinal digestibility of protein.
\end{abstract}

KEY WORDS: cxtrusion-cooking temperature, lupin seeds, fattening lambs 


\section{INTRODUCTION}

Lupin seed protein is rapidly degraded in the rumen, which is why it is poorly utilized. One of the ways of limiting its degradation is extrusion. An additional benefit from extruding feeds containing easily digested protein, aside from limiting the extent of its degradation in the rumen, is the resulting rise in true ileal protein digestibility (Cros et al., 1991; Kibelolaud et al., 1993).

The objective of this experiment was to examine the influence of extrusioncooking temperature on the effective degradability and ileal digestibility of rumen undegraded yellow lupine seeds and to see if extruding lupin seeds improves protein utilization by growing lambs.

\section{MATERIAL AND METHODS}

Twelve Polish Merino male lambs about 85 days old and weighing about $18 \mathrm{~kg}$ were divided into two groups of six animals each. The ration, containing $14 \%$ crude protein $(\mathrm{CP})$ and $11 \%$ crude fibre in dry matter (DM), provided: meadow hay, 10; whole barley grain, 66; dried sugar beet pulp, 14\%. In the control group (RL) the ration was supplemented (about $25 \% \mathrm{CP}$ of the ration) with untreated yellow lupin cv. Juno, in the experimental group (EL), with lupin extrudate (extruder INSTA-PRO 600).

The extrudates used to study the effect of extrusion temperature on the effectiveness of protein degradation in the rumen (deg) and the ileal digestibility of rumen undegraded protein (dsi) were prepared from barley meal $(50 \%)$ and lupin cv. Juno meal $(50 \%)$ at extrusion temperatures of $130,140,150$ and $160^{\circ} \mathrm{C}$. Lambs were fed the extrudate that was characterized by the lowest rumen protein degradability and highest ileal digestibility, prepared at a temperature of $160^{\circ} \mathrm{C}$. The feed was given twice daily, normalizing the daily DM ration according to body weight (BW) of the lambs using the following equation:

$$
\mathrm{DM}_{(\mathrm{kg})}=\left(41.9 \times \mathrm{BW}_{(\mathrm{kg})}-217.6\right) \times 0.0011
$$

Both groups received the same mineral-vitamin supplement of Polfamiks O and Mikrofos. The animals were housed individually on sawdust and had free access to water and salt blocks.

Rumen protein degradation was determined according to Mehrez and Ørskov (1977). Effective rumen protein degradation at $\mathrm{k}_{0.06}$ was computed according to Ørskov and McDonald (1979). Ileal protein digestibility of rumen-undegraded protein was determined according to Hvelplund et al. (1992) by the mobile nylon bag method (mesh size $42 \mu \mathrm{m}$ ). Analysis of feeds was carried out using AOAC (1990) 
methods. Daily body weight gain, DM and CP utilization over 100 days of fattening were determined.

\section{RESULTS AND DISCUSSION}

An increase in the extrusion temperature of a lupin-barley mixture caused a slight decline in the effective degradation of protein in the rumen and a non-significant increase in the intestinal digestibility of rumen undegraded protein (Table 1).

TABLE 1

Influence of increasing extrusion-cooking temperature on ruminal degradability (deg), intestinal digestibility of rumen undegraded protein (dsi) and PDI value, g/kg DM

\begin{tabular}{lcccccr}
\hline & Lupin & \multicolumn{5}{c}{ Extrusion-cooking temperature of lupin-barley } \\
Indices & seeds & \multicolumn{5}{c}{$(1: 1)$ mixture } \\
\cline { 3 - 7 } & & untreated & $130^{\circ}$ & $140^{\circ}$ & $150^{\circ}$ & $160^{\circ}$ \\
\hline Crudc protein, g/kg DM & 410 & & & 270 & \\
deg & 0.85 & 0.80 & 0.70 & 0.68 & 0.67 & 0.67 \\
dsi & 0.59 & 0.71 & 0.92 & 0.93 & 0.94 & 0.94 \\
Degraded in rumen, g & 349 & 216 & 188 & 185 & 182 & 180 \\
Digested in intestine, g & 36 & 38 & 76 & 81 & 84 & 85 \\
PDIN, g & 237 & 164 & 188 & 190 & 192 & 193 \\
PDIE, g & 110 & 112 & 153 & 157 & 160 & 162 \\
\hline
\end{tabular}

Extrusion of the lupin-barley mixture decreased effective rumen protein degradation (to 0.67$)$ in comparison with raw lupin seeds $(0.85)$ and barley grain $(0.75)$ or raw lupin-barley mixture. These results are similar to those of Cros et al. (1991) and Kibelolaud et al. (1993), who found a decline in rumen protein degradation after extrusion of white lupin at temperatures ranging from 110 to $195^{\circ} \mathrm{C}$. An increase in extrusion temperature improved intestinal digestibility of extrudate protein and of PDIN 10 to 32\%, and PDIE 57 to 194\% (Cros et al., 1991).

Extrusion lowered the amount of protein degraded in the rumen by about $13-17 \%$ of the amount degraded from the unextruded mixture (216 vs 180-188 g/ $\mathrm{kg} \mathrm{DM})$. In our experiment, the amount of protein digested in the small intestine after extrusion rose over twofold from 38 to $76-85 \mathrm{~g} / \mathrm{kg} \mathrm{DM}$. We also observed a $15-18 \%$ rise in the PDIN value in the extruded mixture in comparison with the value computed for the mixture not subjected to this process; PDIE rose $37-45 \%$.

Increasing the temperature of barley extrusion from 135 to $155^{\circ} \mathrm{C}$ decreased amount of protein degraded in the rumen by 4 and $20 \%$, respectively, and increased 
amount of rumen undegraded protein digested in small intestine by 25 and $80 \%$, respectively, in relation to the respective value for untreated barley (Table 2).

TABLE 2

Influence of extrusion-cooking temperature of barley grain protein degradability, intestinal digestibility and $\mathrm{PDI}$ value, $\mathrm{g} / \mathrm{kg} \mathrm{DM}$

\begin{tabular}{lccc}
\hline \multirow{2}{*}{ Indices } & \multicolumn{2}{c}{ Extrusion-cooking temperature of barley } \\
\cline { 2 - 4 } & untreated & $135^{\circ} \mathrm{C}$ & $155^{\circ} \mathrm{C}$ \\
\hline Crude protein, g/kg DM & & 137 & \\
\cline { 2 - 4 } deg & 0.75 & 0.72 & 0.60 \\
dsi & 0.83 & 0.91 & 0.92 \\
Degraded in rumen, g & 103 & 99 & 82 \\
Digested in intestine, g & 28 & 35 & 50 \\
PDIN, g & 89 & 93 & 100 \\
PDIE, g & 102 & 109 & 124 \\
\hline
\end{tabular}

Table 3 presents the nutritive value of DM rations determined for the period of 100 days of fattening. At a similar crude protein content (143-145 g in DM) in the rations, the amount of protein digested in the small intestine was $11 \%$ higher when ration EL was fed than RL, similarly, the PDIN content in the ration for group EL lambs was about $15 \%$ higher than for the control lambs.

TABLE 3

Protein degradability and intestinal digestibility of rumen undegraded protein and nutritive value of rations, $\mathrm{g} / \mathrm{kg} \mathrm{DM}$

\begin{tabular}{lcc}
\hline \multirow{2}{*}{ Indices } & \multicolumn{2}{c}{ Group } \\
\cline { 2 - 3 } & control & experimental \\
\hline Crude protein in ration, $g$ & 145 & 143 \\
Protein degraded in the rumen, $g$ & 100 & 96 \\
Protein digested in small intestine, $g$ & 35 & 39 \\
PDIN, g & 93 & 107 \\
PDlE, $g$ & 104 & 126 \\
UFV & 1.1 & 1.2 \\
\hline
\end{tabular}

Body weight gains in the experimental group lambs were about $25 \%$ higher than in the control group (Table 4). Feed utilization was better by 16 (DM) to $18 \%$ (CP) in the group receiving the extrudate than in the control group. Sanson (1992) obtained similar results when feeding soyabean meal extrudate. 
Fattening performance of lambs and feed efficiency

\begin{tabular}{|c|c|c|c|}
\hline \multirow{2}{*}{ Indices } & \multicolumn{2}{|c|}{ Group } & \multirow{2}{*}{ SEM } \\
\hline & control & experimental & \\
\hline \multicolumn{4}{|l|}{ Body weight, $\mathrm{kg}$} \\
\hline initial & $18 . !$ & 18.1 & $0.75^{\mathrm{NS}}$ \\
\hline final & 36.8 & 41.0 & $1.40^{\mathrm{NS}}$ \\
\hline Fattening period, days & 101 & 98 & $1.4^{\mathrm{NS}}$ \\
\hline Daily body gain, $g$ & $186^{\mathrm{a}}$ & $234^{b}$ & $13.8^{1 \leq 0.0 .0 .}$ \\
\hline \multicolumn{4}{|l|}{ Feed intake $/ \mathrm{kg}$ of gain } \\
\hline dry matter, $\mathrm{kg}$ & 5.0 & 4.2 & $0.41^{\mathrm{NS}}$ \\
\hline crude protein, $\mathrm{g}$ & 729 & 597 & $57.5^{\mathrm{NS}}$ \\
\hline
\end{tabular}

\section{CONCLUSIONS}

Increasing the temperature of extrusion of yellow lupin seeds and barley grain decreases rumen protein degradation and markedly increases the amount protein undegraded in rumen and protein digested in small intestine.

Replacing lupin seeds with their extrudate increases the growth rate of lambs and leads to better feed utilization.

\section{REFERENCES}

AOAC, 1990. Association of Official Analytical Chemists. Official Methods of Analysis. $15^{\text {th }}$ Edition. Arlington, VA

Cros P., Benchaar C., Bayourthe C., Vernay M., Moncoulon R., 1991. In situ evaluation of the ruminal and intestinal degradability of extruded whole lupin seed nitrogen. Reprod. Nutr. Develop. 31, 575-583

Hvelplund T., Weisbjerg M.R., Andersen L.S., 1992. Estimation of the true digestibility of rumen undegraded dietary protein in the small intestine of ruminants by the mobile bag technique. Acta Agr. Scand., Sect. A, Anim. Sci. 42, 34-39

Kibelolaud A.R., Vernay M., Bayourthe C., Moncoulon R., 1993. Effect of extruding on ruminal disappearance and lower gastrointestinal tract digestion of white lupin seeds. Can. J. Anim. Sci. $73,57 !-579$

Mehrez A.Z., Ørskov E.R., 1977. A study of the artificial fibre bag technique for determining the digestibility of feeds in the rumen. J. Agr. Sci. 88,645-650

Ørskov E.R., McDonald I., 1979. The estimation of protein degradability in the rumen from incubation measurements weighted according to rate of pasage. J. Agr. Sci. 92, 499-503

Sanson D.W., 1992. Utilization of a low-quality native hay by sheep supplemented with extruded soybeans. Proc. Western Section, Amer. Soc. Anim. Sci. 43, $491-494$ 


\section{STRESZCZENIE}

\section{Wplyw temperatury ekstruzji na wartość pokarmową nasion lubinu w tuezu jagniąt}

Dwanaście jagniąt merynosa polskiego od 18 do ok. 39 kg masy ciała żywiono dawką zawierającą 14\% bialka ogólnego i $11 \%$ włókna surowego w suchej masie. W bialku ogólnym dawki $25 \%$ stanowiło bialko nasion łubinu żółtego lub bialko ckstrudowanej w temperaturze $160^{\circ} \mathrm{C}$ mieszanki zjarna jęczmienia i nasion łubinu (1:1). Elektywny rozkład w żwaczu białka mieszaniny jęczmiennołubinowej wynosił 0,67-0,70; białka nasion łubinu 0,85; ekstrudowanego ziarna jęczmienia 0,600,72 i śruty jęczmiennej 0,75 . Zwiększenie temperatury ekstruzji z 130 do $160^{\circ} \mathrm{C}$ spowodowało niewiclkie tylko zmniejszenie degradacji w żwaczu białka mieszanki jęczmienno-łubinowej z 0,70 do 0,67 i nieistotnie zwiększyło strawność jelitową bialka nie rozłożonego w żwaczu z 0,92 do 0,94 .

Dzienne przyrosty masy ciała jagniąt żywionych dawką z ekstrudowanymi nasionami łubinu były większe niż jagnią̧ karmionych dawką ze śrutą łubinową (234 vs 186 g; $\mathrm{P}<0.05$ ). Jaugnięta otrzymujące ekstruderat zużywały $4,2 \mathrm{~kg}$ s.m. i ok. $600 \mathrm{~g}$ białka ogólnego, jagnięta kontrolne $5,0 \mathrm{~kg}$ s.m. i ok. $730 \mathrm{~g}$ bialka ogólnego na kg przyrostu.

Zastąpienie nasion łubinu ekstruderatem obniżyło stopień degradacji białka w żwaczu oraz zwiększyło efektywność tuczu jagniąt. Zwiększenie temperatury ekstruzji powyżej $130^{\circ} \mathrm{C}$ nie miało istotnego wpływu na wielkość rozkładu w żwaczu oraz strawność jelitową białka. 